\title{
Doksycyklina w terapii amyloidozy układowej z zajęciem serca
}

\author{
Doxycycline in the treatment of systemic amyloidosis \\ with cardiac involvement
}

\author{
Justyna Łyczkowska-Piotrowska ${ }^{1}$, Aleksander Salomon-Perzyński ${ }^{2}$, \\ Agnieszka Końska ${ }^{2}$, Krzysztof Jamroziak ${ }^{2}$ \\ ${ }^{1}$ Klinika Kardiologii i Nadciśnienia Tętniczego, Centralny Szpital Kliniczny \\ Ministerstwa Spraw Wewnętrznych i Administracji, Warszawa \\ ${ }^{2}$ Klinika Hematologii, Instytut Hematologii i Transfuzjologii, Warszawa
}

\begin{abstract}
Streszczenie
$W$ leczeniu chorych na amyloidozy uktadowe dominuja obecnie strategie ukierunkowane na zmniejszenie produkcji biatek prekursorowych amyloidu. Takie podejście jest między innymi reprezentowane przez stosowanie chemioterapii w amyloidozie tańcuchów lekkich (amyloidozie AL) lub transplantacje watroby czy próby supresji ekspresji genu transtyretyny u chorych na amyloidozy transtyretynowe (ATTR). Ostatnio jednak coraz aktywniej sq rozwijane terapie stużce ograniczeniu powstawania amyloidu z krażacych prekursorów lub eliminacji już uformowanych depozytów amyloidowych. Do tej grupy metod można zaliczyć przewlekte stosowanie doksycykliny, powszechnie znanego antybiotyku bakteriostatycznego z grupy tetracyklin. W badaniach przedklinicznych wykazano, że potencjat antyamyloidogenny doksycykliny w amyloidozie AL polega zarówno na interferencji w proces amyloidogenezy, jak $i$ destrukcji depozytów amyloidowych. Kliniczne badania retrospektywne wskazuja, ze doksycyklina stosowana wraz ze standardowa chemioterapia poprawia rokowanie u chorych na amyloidoze AL z zajeciem serca, którzy stanowia najgorzej rokujaca grupe pacjentów, zachowujac przy tym korzystny profil bezpieczeństwa terapii. Z kolei wydaje sie, ze w ATTR doksycyklina stablizuje przebieg kliniczny choroby. W pracy dokonano przegladu piśmiennictwa dotyczacego roli doksycykliny w leczeniu chorych na amyloidozy uktadowe.
\end{abstract}

Słowa kluczowe: amyloidoza łańcuchów lekkich, amyloidoza serca, amyloidoza transtyretynowa, doksycyklina

Hematologia 2018; 9, 3: 202-207

\begin{abstract}
The leading strategy in the management of patients with systemic amyloidosis is currently focused on reducing the production of amyloid precursor proteins. This approach is based on the use of chemotherapy in light chain amyloidosis (AL amyloidosis) or liver transplantation, or attempts to suppress transthyretin gene expression in patients with transthyretin amyloidosis (ATTR). Recently, however, therapies have been increasingly developed to reduce the formation of amyloid deposits from circulating precursors or to eliminate already formed amyloid deposits. This approach includes, in particular, the chronic use of doxycycline, a well-known bacteriostatic antibiotic from
\end{abstract}

Adres do korespondencji: Aleksander Salomon-Perzyński, Klinika Hematologii, Instytut Hematologii i Transfuzjologii, ul. Indiry Gandhi 14, 02-776 Warszawa, faks 223496 335, e-mail: salomon.perzynski@gmail.com 
the tetracycline group. In preclinical studies it was shown that the anti-amyloidogenic potential of doxycycline in AL amyloidosis depends on interference in the process of amyloidogenesis and the destruction of amyloid deposits. Clinical retrospective studies indicate that doxycycline used with standard chemotherapy improves prognosis in patients with AL amyloidosis with heart involvement, which is the most unfavorable prognostic group, while maintaining a favorable safety profile of therapy. In contrast, in ATTR, doxycycline appears to stabilize the clinical course of the disease. In this paper, we review literature on the role of doxycycline in the treatment of patients with systemic amyloidosis.

\section{Key words: light chain amyloidosis, cardiac amyloidosis, transthyretine amyloidosis, doxycycline}

Hematologia 2018; 9, 3: 202-207

\section{Wprowadzenie}

Amyloidozy układowe stanowią rzadką grupę schorzeń, w patogenezie których dominującą rolę odgrywa odkładanie się w macierzy pozakomórkowej różnych tkanek i narządów depozytów amyloidowych, czyli nieprawidłowo sfałdowanych, amorficznych, nierozpuszczalnych białek o budowie włókienkowej [1-3]. Obecnie jest znanych ponad 36 różnych białek prekursorowych, natywnych lub zmutowanych, które mogą tworzyć włókienka amyloidowe, potencjalnie niemal we wszystkich tkankach i narządach, i przyczyniać się do rozwoju objawów choroby u człowieka [1-3]. Mimo zróżnicowanej budowy biochemicznej wspólną cechą białek amyloidogennych jest zdolność do tworzenia charakterystycznej struktury konformacyjnej określanej jako struktura beta (beta-harmonijka), która powoduje charakterystyczną dwójłomność $\mathrm{w}$ świetle spolaryzowanym po wybarwieniu czerwienią Kongo [1, 3].

Wobec rzadkości występowania, heterogennej prezentacji klinicznej i złożonej diagnostyki amyloidoz układowych wiedza na temat epidemiologii tych chorób pozostaje ograniczona. Zapadalność na amyloidozę łańcuchów lekkich (amyloidozę AL), najczęstszy podtyp amyloidozy układowej (70-80\% wszystkich chorych), szacuje się na 1-1,5 przypadków/100 tys. osób rocznie, przy czym należy zastrzec, że dane te mogą być niedoszacowane [4]. Większość zachorowań na amyloidozę AL dotyczy osób powyżej 65. roku życia, a mężczyźni chorują 2-krotnie częściej niż kobiety [5]. Białko prekursorowe amyloidu $\mathrm{w}$ amyloidozie AL stanowią monoklonalne wolne łańcuchy lekkie immunoglobulin (FLC, free light chains) lambda lub kappa produkowane przez patologiczny, niewielki rozrost plazmocytowy w szpiku kostnym [5].

Amyloidozy transtyretynowe (ATTR, transthyretin amyloidosis) stanowią 15-20\% ogólu amyloidoz układowych [6]. W grupie tej dominuje nabyta ATTR typu dzikiego (ATTRwt, ATTR wild-type) (ok. 10\% wszystkich przypadków amyloidoz układowych), określana dawniej mianem amyloidozy starczej, w przebiegu której dochodzi do odkładania się w mięśniu sercowym depozytów amyloidowych zbudowanych $z$ niezmutowanej postaci transtyretyny (TTR) [7]. Typ ATTRwt dotyczy głównie populacji osób starszych. W przeszłości uważano, że jest to choroba wyjątkowo rzadka, obecnie jednak postrzega się ją jako coraz częstszą przyczynę niewydolności serca u osób starszych [8]. Około 7\% przypadków amyloidoz układowych stanowi postać dziedziczna ATTR związana $z$ różnymi mutacjami genu transtyretyny (ATTRm) [6]. Transtyretyna (określana inaczej jako prealbumina) jest białkiem transportowym dla tyroksyny i retinolu syntetyzowanym głównie w wątrobie. W postaci niezmutowanej TTR ma budowę tetrameryczną. W wyniku mutacji punktowych w genie TTR tetramer ulega dysocjacji do monomerów. Monomery jako podjednostki niestabilne ulegają nieprawidłowemu sfałdowaniu, stając się białkami amyloiodgennymi [7, 9]. Znanych jest ponad 120 mutacji TTR, co przekłada się na zróżnicowany obraz kliniczny choroby [10].

Ze względu na możliwość zajęcia tych samych narządów w różnych typach amyloidoz układowych zasadniczo nie da się ustalić podtypu choroby na podstawie fenotypu klinicznego. Należy szczególnie podkreślić, że do rozpoznania amyloidozy AL nie upoważnia samo stwierdzenie złogów amyloidowych i współwystępującej gammapatii monoklonalnej [11]. Szacuje się, że przy takim podejściu diagnostycznym co 10. pacjent jest błędnie zdiagnozowany, a co za tym idzie - niewłaściwie leczony [6]. Wynika to przede wszystkim $z$ wysokiej częstość gammapatii monoklonalnej o nieustalonym znaczeniu (MGUS, monoclonal gammapathy of unknown significance) w populacji osób starszych [6]. Dlatego typowanie amyloidu, a więc identyfikacja białka amyloidogennego na podstawie analizy struktury depozytów amyloidowych za pomocą badania immunohistochemicznego, spektrometrii mas lub immunomikroskopii elektronowej, ma 
podstawowe znaczenie $\mathrm{w}$ ustalaniu rozpoznania typu amyloidozy i w konsekwencji doboru odpowiedniej terapii [12].

\section{Amyloidoza serca}

Zajęcie serca w przebiegu amyloidoz może mieć charakter izolowany lub współwystępować z zajęciem innych narządów. Dotychczas zidentyfikowano dziewięć białek prekursorowych amyloidu, które mogą powodować amyloidozę serca. Zalicza się do nich FLC kappa i lambda, apolipoproteinę I (apoA-I), transtyretynę zmutowaną (TTRm, $m u$ tated transthyretin), transtyretynę typu dzikiego (TTRwt, transthyretin wilde-type), surowiczy amyloid A (SSA, serum amyloid A), przedsionkowy peptyd natriuretyczny (ANP, atrial natriuretic peptide) i beta ${ }_{2}$-mikroglobulinę [13].

Zajęcie mięśnia sercowego, stwierdzane w 50 $-60 \%$ przypadków amyloidozy AL [14], stanowi główny niekorzystny czynnik rokowniczy i w znaczącym stopniu determinuje postępowanie terapeutyczne $\mathrm{w}$ tej jednostce chorobowej [12]. Mediana przeżycia chorych na amyloidozę AL w III stopniu zaawansowania klinicznego według klasyfikacji Mayo Clinic 2004, a więc chorych $z$ istotnym zajęciem serca (stężenie N-końcowego fragmentu propeptydu natriuretycznego typu B [NT-proBNP, $N$-terminal pro-B-type natriuretic peptide $]>332 \mathrm{ng} /$ l i stężenie troponiny $\mathrm{T}>0,035 \mathrm{ng} /$ $/ \mathrm{ml})$ wynosi 7 miesięcy $[15,16]$. U nieleczonych pacjentów $z$ amyloidozą AL wykazujących podmiotowe i przedmiotowe objawy niewydolności serca (HF, heart failure) przeżycie całkowite (OS, overall survival) nie przekracza 12 miesięcy [17].

Natomiast w przebiegu ATTR zajęcie serca cechuje się indolentnym przebiegiem klinicznym oraz powolną progresją do HF. Rokowanie nieleczonych chorych na ATTR jest dużo lepsze niż pacjentów $z$ amyloidozą $A L$, wyrażające się czasami przeżycia liczonymi w latach lub dekadach. Odsetek chorych na ATTRm przeżywających 5 lat wynosi $75 \%$ [18], $z$ kolei mediana OS w grupie chorych na ATTRwt to 75 miesięcy [19].

Patomechanizm prowadzący do objawowej $\mathrm{HF}$ u pacjentów $\mathrm{z}$ rozpoznaniem amyloidozy jest złożony [14, 15]. Odkładanie się depozytów amyloidowych w tkance śródmiąższowej mięśniówki serca przyczynia się do pogrubienia jego ścian, zmniejszenia podatności i postępującej dysfunkcji rozkurczowej. Sztywne i niepodatne ściany komór serca powodują wzrost ciśnienia napełniania i w rezultacie powiększenie przedsionków. Wraz $z$ progresją choroby może dochodzić do martwicy kardiomiocytów oraz ogniskowego włóknienia śródmiąższowego, co w konsekwencji prowadzi do dysfunkcji skurczowej. Odkładanie się złogów amyloidowych we wsierdziu sprzyja rozwojowi nabytych wad zastawkowych, zajęcie układu przewodzącego - zaburzeniom rytmu, $z$ kolei zajęcie naczyń mikrokrążenia oraz błony środkowej i przydanki tętnic wieńcowych - chorobie niedokrwiennej serca [14]. W patogenezie molekularnej postępującej HF w przebiegu amyloidozy AL bierze się również pod uwagę kardiotoksyczny wplyw indukowanej przez depozyty amyloidowe lokalnej reakcji zapalnej i stresu oksydacyjnego [20]. Ponadto podkreśla się bezpośredni efekt cytotoksyczny, jaki wywierają amyloidogenne FLC na kardiomiocyty [21-23].

Biorąc zatem pod uwagę powyższe dane, w celu osiągnięcia optymalnych wyników leczenia amyloidozy AL serca, $z$ jednej strony, kluczowe jest uzyskanie szybkiej i głębokiej odpowiedzi hematologicznej, czyli znacznego obniżenia stężenia FLC eliminującego ich potencjał do tworzenia nowych złogów amyloidu oraz bezpośrednią kardiotoksyczność. $Z$ drugiej strony, równie istotne wydaje się prowadzenie odpowiedniej terapii wspomagającej, obejmującej zarówno adekwatne postępowanie kardiologiczne, jak i wykorzystanie leków o potencjale antyamyloidogennym (zaburzających proces formowania się depozytów amyloidowych) lub antyamyloidowym (zapobiegających toksyczności tkankowej/narządowej indukowanej przez depozyty amyloidowe).

\section{Mechanizm działania doksycykliny w amyloidozie}

W leczeniu amyloidoz układowych obecnie rozwijane są strategie ukierunkowane na zapobieganie dalszemu formowaniu się depozytów amyloidowych, w tym między inymi chemioterapia w celu eradykacji klonu plazmocytarnego w przypadku amyloidozy AL [5] oraz próby farmakologicznej supresji ekspresji genu TTR [24] i stabilizacji prawidłowej konformacji białka TTR w odniesieniu do ATTR [25]. Drugim równorzędnym kierunkiem badań jest rozwój terapii służących eliminacji już uformowanych depozytów amyloidowych. Zalicza się do nich między innymi monoklonalne przeciwciała antyamyloidowe [26], doksycyklinę [27, 28] i kwas tauroursodeoksycholowy (TUDCA, tauroursodeoxycholic acid) [29].

Na potencjał antyamyloidogenny doksycykliny, antybiotyku bakteriostatycznego z grupy tetracyklin, wskazują wyniki kilku badań przedklinicznych 
[30-34]. W modelach zwierzęcych amyloidozy AL doksycyklina zarówno interferowała $z$ procesem formowania depozytów amyloidowych, jak i znosiła bezpośredni efekt kardiotoksyczny wywierany przez nieprawidłowe lańcuchy lekkie [30-32]. W transgenicznym modelu mysim ATTR doksycyklina nasilała procesy degradacji depozytów amyloidowych [33], wykazując przy tym synergistyczną aktywność z TUDCA [34]. Podobnie, w przypadku amyloidozy związanej z dializoterapią, zależnie od osiąganego in vitro stężenia doksycykliny obserwowano zahamowanie amyloidogenezy lub destrukcję już uformowanych złogów amyloidowych, dla których komponentem prekursorowym była beta $_{2}$-mikroglobulina [35].

\section{Znaczenie kliniczne doksycykliny w leczeniu amyloidozy AL $\mathrm{z}$ zajęciem serca}

Pierwsze dane na temat skuteczności klinicznej stosowania doksycykliny w ramach terapii wspomagającej w amyloidozie AL przedstawili $\mathrm{Ku}-$ mar i wsp. [36]. Do analizy włączono 455 chorych na amyloidozę AL poddanych wysokodawkowanej chemioterapii wspomaganej autologicznym przeszczepieniem krwiotwórczych komórek macierzystych (auto-HSCT, therapy autologous hematopoietic stem cell trasnplantation). U 77\% chorych w ramach profilaktyki powikłan infekcyjnych po auto-HSCT stosowano pochodną penicyliny, pozostali pacjenci (23\%) otrzymywali doksycyklinę. Mediana OS w całej grupie wyniosła 161 miesięcy. Pacjenci, u których uzyskano odpowiedź hematologiczną po auto-HSCT, leczeni doksycykliną osiagali istotnie dłuższe OS niż chorzy otrzymujący penicylinę (mediana OS odpowiednio: nieosiagnięta i 161 miesięcy; $\mathrm{p}=0,04)$. Korzyści $z$ leczenia doksycykliną nie obserwowano $\mathrm{w}$ grupie chorych, którzy nie uzyskali odpowiedzi hematologicznej, co sugeruje zależność potencjału antyamyloidoegennego doksycykliny od obciążenia białkiem prekursorowym amyloidu [36].

Na skuteczność kliniczną doksycykliny w leczeniu amyloidozy AL wskazują również wyniki niedawno opublikowanej analizy retrospektywnej przeprowadzonej przez Wechalekara i Whelana [27]. Badaniem objęto 30 chorych na amyloidozę AL leczonych w pierwszej linii według standardowego schematu chemioterapii w skojarzeniu $z$ doksycykliną; wyniki leczenia $\mathrm{w}$ badanej grupie porównywano $z$ wynikami odpowiednio dobranej grupy kontrolnej. Co ważne, 83\% badanej grupy stanowili pacjenci $z$ amyloidozą AL w stopniu za- awansowania klinicznego III według klasyfikacji Mayo Clinic z 2004 roku, czyli z zaawansowanym zajęciem serca. W tym badaniu doksycyklinę podawano doustnie w dawce 2 razy $100 \mathrm{mg} /$ dobę. Mediana czasu trwania leczenia doksycykliną wyniosła 6 miesięcy (zakres 1-24 mies.); u 10\% pacjentów leczenie przerwano $z$ powodu wystąpienia działań niepożądanych leku. Pacjenci leczeni doksycykliną znamiennie częściej osiągali odpowiedź hematologiczną (całkowity odsetek odpowiedzi [ORR, overall response rate] $93 \%$ v. 59\%), w tym odpowiedź całkowitą ([CR, complete response] $56 \%$ v. 35\%). Podobnie istotnie częściej w grupie tej obserwowano odpowiedź sercową (60\% v. 18\%). Co najbardziej ważne, leczenie doksycykliną wiązało się $z$ istotną poprawą OS (mediana nieosiągnięta $v .13$ miesięcy), jednak poprawa rokowania nie dotyczyła pacjentów $z$ chorobą w najwyższym stopniu zaawansowania IIIb według klasyfikacji Mayo Clinic z 2004 roku. W grupie otrzymującej doksycyklinę 12- i 24-miesięczne przeżycie osiągnęło odpowiednio $82 \%$ i $53 \%$ chorych ( $v .82 \%$ i $40 \%$ w grupie kontrolnej). Korzyści z leczenia doksycykliną obserwowano w szczególności u pacjentów zarówno $z$ chorobą w stopniu zaawansowania IIIa, jak i z wysokim wyjściowym stężeniem troponiny T. Korzystny wpływ doksycykliny na wyniki leczenia obserwowano również u chorych leczonych według schematów chemioterapii opartych na bortezomibie (mediana OS nieosiągnięta $\mathrm{w}$ grupie leczonej doksycykliną v. 15 miesięcy w grupie kontrolnej) [27].

W celu potwierdzenia obiecujących wyników analiz retrospektywnych ostatnio zainicjowano prospektywne badanie II fazy służące ocenie skuteczności klinicznej i profilu bezpieczeństwa stosowania doksycykliny podawanej doustnie $\mathrm{w}$ dawce 2 razy $100 \mathrm{mg} /$ dobę przez 12 miesięcy jako uzupełnienia standardowego leczenia chorych na amyloidozę AL (badanie DUAL [Doxycycline to Upgrade Organ Response in Light Chain (AL) Amyloidosis]; NCT02207556) [37].

\section{Aktywność doksycykliny w leczeniu pacjentów z ATTR}

Skuteczność doksycykliny w skojarzeniu $z$ TUDCA u chorych $z$ rozpoznaniem amyloidozy ATTR dotychczas oceniono w jednym badaniu II fazy [29]. Do badania włączono łącznie 20 pacjentów, w tym 17 chorych $z$ rozpoznaniem ATTRm i 2 chorych $z$ podtypem ATTRwt. Leczenie skojarzone prowadzono przez 12 miesięcy. Odpowiednio 50\% i $35 \%$ pacjentów ukończyło 6- i 12 -miesięczny okres terapii. U $10 \%$ pacjentów konieczne było 
przerwanie leczenia $z$ powodu nieakceptowalnej toksyczności. W czasie leczenia nie obserwowano progresji zarówno HF, jak i polineuropatii, co sugeruje, że terapia skojarzona wykazuje stabilizujący wpływ na przebieg kliniczny ATTR. Wobec zachęcających wyników zainicjowano kolejne badanie II fazy, w którym zostaną ocenione aktywność kliniczna i profil bezpieczeństwa doksycykliny w skojarzeniu $z$ kwasem ursodeoksycholowym w leczeniu pacjentów z ATTR [38].

\section{Doksycyklina w leczeniu pacjentów $\mathrm{z}$ amyloidozą podializacyjną}

Na potencjalne korzyści wynikające $z$ przewlekłego stosowania doksycykliny $\mathrm{w}$ amyloidozie związanej $z$ dializoterapią wskazują pojedyncze opisy przypadków klinicznych. Montagna i wsp. [39] opisali 3 chorych, u których obserwowano znaczące złagodzenie artralgii w czasie stosowania dokycykliny w dawce $100 \mathrm{mg} /$ dobę. Efekt analgetyczny doksycykliny $\mathrm{w}$ artropatii $\mathrm{w}$ przebiegu amyloidozy związanej z hemodializoterapią obserwowali również Piccoli i wsp. [40]. Efekt ten wydawał się niezależny od przeciwzapalnej aktywności doksycykliny i najpewniej wynikał $z$ interakcji doksycykliny z depozytami amyloidowymi w kośćcu [40].

\section{Podsumowanie}

Coraz więcej danych klinicznych wskazuje na korzyści wynikające ze stosowania doksycykliny w dwóch najczęstszych typach amyloidoz układowych przebiegających $z$ zajęciem mięśnia sercowego. Co ważne, w świetle aktualnej literatury doksycyklina poprawia rokowanie $u$ chorych na amyloidozę AL (w skojarzeniu ze standardową terapią ukierunkowaną na eradykację klonu plazmocytarnego) i ATTR, nie pogarszając istotnie profilu bezpieczeństwa terapii. Nie bez znaczenia pozostaje także stosunkowo niski koszt leczenia.

Aktywność kliniczna doksycykliny, zwłaszcza $\mathrm{w}$ grupie chorych na amyloidozę AL, wymaga potwierdzenia w prospektywnych badaniach randomizowanych. Dalsze badania powinny określić optymalne dawkowanie leku, jak również optymalny czas stosowania doksycykliny.

\section{Konflikt interesów}

Autorzy nie deklarują istnienia konfliktu interesów.

\section{Piśmiennictwo}

1. Milani P, Merlini G, Palladini G. Novel Therapies in Light Chain Amyloidosis. Kidney Int Rep. 2018; 3(3): 530-541, doi: 10.1016/j. ekir.2017.11.017, indexed in Pubmed: 29854961.

2. Westermark P, Benson MD, Buxbaum JN, et al. Nomenclature Committee of the International Society of Amyloidosis. Amyloid: toward terminology clarification. Report from the Nomenclature Committee of the International Society of Amyloidosis. Amyloid. 2005; 12(1): 1-4, doi: 10.1080/13506120500032196, indexed in Pubmed: 16076605.

3. Zhang C, Huang X, Li J. Light chain amyloidosis: Where are the light chains from and how they play their pathogenic role? Blood Rev. 2017; 31(4): 261-270, doi: 10.1016/j.blre.2017.03.002, indexed in Pubmed: 28336182.

4. Quock TP, Yan T, Chang E, et al. Epidemiology of AL amyloidosis: a real-world study using US claims data. Blood Adv. 2018; 2(10): 1046-1053, doi: 10.1182/bloodadvances.2018016402, indexed in Pubmed: 29748430.

5. Milani P, Merlini G, Palladini G. Light Chain Amyloidosis. Mediterr J Hematol Infect Dis. 2018; 10(1): e2018022, doi: 10.4084/ /MJHID.2018.022, indexed in Pubmed: 29531659.

6. Palladini G, Merlini G. What is new in diagnosis and management of light chain amyloidosis? Blood. 2016; 128(2): 159-168, doi: 10.1182/blood-2016-01-629790.

7. Ton VK, Mukherjee M, Judge DP. Transthyretin cardiac amyloidosis: pathogenesis, treatments, and emerging role in heart failure with preserved ejection fraction. Clin Med Insights Cardiol. 2014; 8(Suppl 1): 39-44, doi: 10.4137/CMC.S15719, indexed in Pubmed: 25628512.

8. Hemminki K, Li X, Försti A, et al. Incidence and survival in nonhereditary amyloidosis in Sweden. BMC Public Health. 2012; 12: 974, doi: 10.1186/1471-2458-12-974, indexed in Pubmed: 23148499 .

9. Rocha A, Lobato L, Lobato L, et al. Transthyretin amyloidosis and the kidney. Clin J Am Soc Nephrol. 2012; 7(8): 1337-1346, doi: 10.2215/CJN.08720811, indexed in Pubmed: 22537653.

10. Hörnsten R, Pennlert J, Wiklund U, et al. Heart complications in familial transthyretin amyloidosis: impact of age and gender. Amyloid. 2010; 17(2): 63-68, doi: 10.3109/13506129.2010.483114, indexed in Pubmed: 20462364.

11. Dispenzieri A, Buadi F, Kumar SK, et al. Treatment of immunoglobulin light chain amyloidosis: Mayo Stratification of Myeloma and Risk-Adapted Therapy (mSMART) Consensus Statement. Mayo Clin Proc. 2015; 90(8): 1054-1081, doi: 10.1016/j.mayocp.2015.06.009, indexed in Pubmed: 26250727.

12. Gavriatopoulou M, Musto P, Caers Jo, et al. European myeloma network recommendations on diagnosis and management of patients with rare plasma cell dyscrasias. Leukemia. 2018; 32(9): 1883-1898, doi: 10.1038/s41375-018-0209-7, indexed in Pubmed: 30038381.

13. Guan J, Mishra S, Falk RH, et al. Current perspectives on cardiac amyloidosis. Am J Physiol Heart Circ Physiol. 2012; 302(3): H544-H552, doi: 10.1152/ajpheart.00815.2011, indexed in Pubmed: 22058156.

14. Dahm CN, Cornell RF, Lenihan DJ. Advances in Treatment of Cardiac Amyloid. Curr Treat Options Cardiovasc Med. 2018; 20(5): 37, doi: 10.1007/s11936-018-0631-1, indexed in Pubmed: 29627865. 
15. Dispenzieri A, Gertz M, Kyle R, et al. Serum cardiac troponins and N-terminal pro-brain natriuretic peptide: a staging system for primary systemic amyloidosis. J Clin Oncol. 2004; 22(18): 3751-3757, doi: 10.1200/jco.2004.03.029.

16. Wechalekar AD, Schonland SO, Kastritis E, et al. A European collaborative study of treatment outcomes in 346 patients with cardiac stage III AL amyloidosis. Blood. 2013; 121(17): 3420-3427, doi: 10.1182/blood-2012-12-473066, indexed in Pubmed: 23479568.

17. Dubrey SW, Cha K, Anderson J, et al. The clinical features of immunoglobulin light-chain (AL) amyloidosis with heart involvement. QJM. 1998; 91(2): 141-157, doi: 10.1093/qjmed/91.2.141, indexed in Pubmed: 9578896.

18. Rapezzi C, Merlini G, Quarta CC, et al. Systemic cardiac amyloidoses: disease profiles and clinical courses of the 3 main types. Circulation. 2009; 120(13): 1203-1212, doi: 10.1161/CIRCULATIONAHA.108.843334, indexed in Pubmed: 19752327.

19. Ng B, Connors LH, Davidoff R, et al. Senile systemic amyloidosis presenting with heart failure: a comparison with light chain-associated amyloidosis. Arch Intern Med. 2005; 165(12): 1425-1429, doi: 10.1001/archinte.165.12.1425, indexed in Pubmed: 15983293.

20. Falk RH, Alexander KM, Liao R, et al. AL (light-chain) cardiac amyloidosis: a review of diagnosis and therapy. J Am Coll Cardiol. 2016; 68(12): 1323-1341, doi: 10.1016/j.jacc.2016.06.053, indexed in Pubmed: 27634125.

21. Mishra S, Guan J, Plovie E, et al. Human amyloidogenic light chain proteins result in cardiac dysfunction, cell death, and early mortality in zebrafish. Am J Physiol Heart Circ Physiol. 2013; 305(1): H95-H103, doi: 10.1152/ajpheart.00186.2013, indexed in Pubmed: 23624626.

22. Lavatelli F, Imperlini E, Orrù S, et al. Novel mitochondrial protein interactors of immunoglobulin light chains causing heart amyloidosis. FASEB J. 2015; 29(11): 4614-4628, doi: 10.1096/ /fj.15-272179, indexed in Pubmed: 26220173.

23. Oberti L, Rognoni P, Barbiroli A, et al. Concurrent structural and biophysical traits link with immunoglobulin light chains amyloid propensity. Sci Rep. 2017; 7(1): 16809, doi: 10.1038/s41598-01716953-7, indexed in Pubmed: 29196671.

24. Havens MA, Hastings ML. Splice-switching antisense oligonucleotides as therapeutic drugs. Nucleic Acids Res. 2016; 44(14): 6549-6563, doi: 10.1093/nar/gkw533, indexed in Pubmed: 27288447.

25. Maurer MS, Schwartz JH, Gundapaneni B, et al. ATTR-ACT Study Investigators. Tafamidis treatment for patients with transthyretin amyloid cardiomyopathy. N Engl J Med. 2018; 379(11): 1007-1016, doi: 10.1056/NEJMoa1805689, indexed in Pubmed: 30145929 .

26. Edwards CV, Gould J, Langer AL, et al. Final analysis of the phase 1a/b study of chimeric fibril-reactive mono-clonaL ANTIBODY 11-1F4 in patients with relapsed or refractory AL amyloidosis. Am Soc Hematol. 2017; 130(Suppl 1): 509.

27. Wechalekar AD, Whelan C. Encouraging impact of doxycycline on early mortality in cardiac light chain (AL) amyloidosis. Blood Cancer J. 2017; 7(3): e546, doi: 10.1038/bcj.2017.26, indexed in Pubmed: 28338670.

28. Salomon-Perzyński A, Końska A, Puła B. Jak leczymy pacjenta $z$ nowo rozpoznaną amyloidozą łańcuchów lekkich pośredniego ryzyka? Rola doksycykliny w terapii amyloidozy z zajęciem serca. Hematologia. 2018; 9(3): 245-253, doi: 10. Hem. 2018; 9(3): 26, doi: 10.5603/ Hem.2018.0031.

29. Obici L, Cortese A, Lozza A, et al. Doxycycline plus tauroursodeoxycholic acid for transthyretin amyloidosis: a phase II study. Amyloid. 2012; 19(Suppl 1): 34-36, doi: 10.3109/ /13506129.2012.678508, indexed in Pubmed: 22551192.

30. Ward JE, Ren R, Toraldo G, et al. Doxycycline reduces fibril formation in a transgenic mouse model of AL amyloidosis. Blood. 2011; 118(25): 6610-6617, doi: 10.1182/blood-2011-04-351643, indexed in Pubmed: 21998211.

31. Hata H, Sugimoto T, Ueda M, et al. Amyloid fibril formation of immunoglobulin light chain peptide from IHC-negative $\mathrm{AL}$ amyloidosis and its inhibition by doxycycline and epigallocatechin. Blood. 2017; 130(Suppl 1): 5331.

32. Diomede L, Rognoni P, Lavatelli F, et al. A Caenorhabditis elegans-based assay recognizes immunoglobulin light chains causing heart amyloidosis. Blood. 2014; 123(23): 3543-3552, doi: 10.1182/ /blood-2013-10-525634, indexed in Pubmed: 24665135.

33. Cardoso I, Saraiva MJ. Doxycycline disrupts transthyretin amyloid: evidence from studies in a FAP transgenic mice model. FASEB J. 2006; 20(2): 234-239, doi: 10.1096/fj.05-4509com, indexed in Pubmed: 16449795.

34. Cardoso I, Martins D, Ribeiro T, et al. Synergy of combined doxycycline/TUDCA treatment in lowering transthyretin deposition and associated biomarkers: studies in FAP mouse models. J Transl Med. 2010; 8(1): 74, doi: 10.1186/1479-5876-8-74, indexed in Pubmed: 20673327.

35. Giorgetti S, Raimondi S, Pagano K, et al. Effect of tetracyclines on the dynamics of formation and destructuration of beta ${ }_{2}$-microglobulin amyloid fibrils. J Biol Chem. 2011; 286(3): 2121-2131, doi: 10.1074/jbc.M110.178376, indexed in Pubmed: 21068391.

36. Kumar SK, Dispenzieri A, Lacy MQ, et al. Doxycycline used as post transplant antibacterial prophylaxis improves survival in patients with light chain amyloidosis undergoing autologous stem cell trans- plantation. Blood. 2012; 120(21): 3138.

37. D'Souza A, Flynn K, Chhabra S, et al. Rationale and design of DUAL study: doxycycline to upgrade response in light chain (AL) amyloidosis (DUAL): a phase 2 pilot study of a two-pronged approach of prolonged doxycycline with plasma cell-directed therapy in the treatment of $\mathrm{AL}$ amyloidosis. Contemp Clin Trials Commun. 2017; 8: 33-38, doi: 10.1016/j.conctc.2017.08.012, indexed in Pubmed: 29696194.

38. Wixner J, Pilebro B, Lundgren HE, et al. Effect of doxycycline and ursodeoxycholic acid on transthyretin amyloidosis. Amyloid. 2016; 24(Suppl 1): 78-79, doi: 10.1080/13506129.2016.1269739.

39. Montagna G, Cazzulani B, Obici L, et al. Benefit of doxycycline treatment on articular disability caused by dialysis related amyloidosis. Amyloid. 2013; 20(3): 173-178, doi: 10.3109/13506129.2013.803463, indexed in Pubmed: 23734692.

40. Piccoli GB, Hachemi M, Molfino I, et al. Doxycycline treatment in dialysis related amyloidosis: discrepancy between antalgic effect and inflammation, studied with FDG-positron emission tomography: a case report. BMC Nephrol. 2017; 18(1): 285, doi: 10.1186/ /s12882-017-0698-z, indexed in Pubmed: 28874122. 